\title{
DEVELOPED MUSIC TEACHING KIT OF PAKEM FOR ELEMENTARY SCHOOL MUSIC LEARNING
}

\author{
Yoyok Yermiandhoko \\ State University of Surabaya, Indonesia \\ Jl. Ketintang Surabaya Indonesia 60231 \\ E-mail: yock.pgsd@yahoo.com
}

Received: December 2013. Accepted: Februari 2014. Published: Maret 2014

\begin{abstract}
The objective of the research was to: (1) construct a model and develop a music teaching kit of $P A K E M$ which were appropriately applied to the music teaching learning process in the third grade of elementary schools; (2) describe the level of conceptual feasibility; (3) describe the level of operational feasibility; and (4) describe the level of effectiveness of the music teaching kit of PAKEM developed. This research uses eight steps of development which is the modification of 10 steps of Borg \& Galldevelopment research. The data to be analyzed included (1) the observation data of teachers and students; (2) the survey form for teachers and students; (3) the students' learning result of music class; and (4) the result of students' performance of musical ability. The results of development research indicated that the music teaching kit developed: (1) can be used by teachers without encountering difficulties; (2) can last eliminating difficulties and limitations in conducting music teacher learning process; (3) is able to engage students actively; (4) is capable of motivating students to enjoy learning music; and (5) is able to improve the results of music learning in theory and practice.
\end{abstract}

(C) 2014 Sendratasik FBS UNNES

Keywords: development; teaching kit; music art; PAKEM

\section{INTRODUCTION}

As stated in government regulation of national standards of education to elementary school level, the charge in elementary subjects covering five groups of subjects: (1) religion and morals; (2) civics and personality; (3) science and technology; (4) aesthetics; and (5) physical education, sports and health. From those groups of subjects it appears that the field of aesthetics (art and cultural studies) gained no difference from other fields, since the framers of the education curriculum policy realize that art education has important and strategic roles to support students' development, especially in the realm of creativity, expression, and aesthetics. Besi- des, inelementary school age (6 to 13 years) children are in the stage of imaginationdevelopment, involving in living up, interpreting, and appreciatingworks of art, so the impact of these activities of appreciation is very positive in shaping children's behavior and mental character.

Some research results and opinions of the experts stated that the positive effect of music and art is important to education and children's development. Jazuli (2008, p. 4) stated that practicing or playing music will contribute positively towards academic ability. Even in the current study, children who learn piano have spatial temporal reasoning about $30 \%$ better than the children who learn computer. It can be found some opinionsin the summary 
of the Bulletin of the Council for Research in Music Education that (1) music or art education will facilitate the development of children in the language and the speed of reading; (2) a musical or artistic activity is highly valued for children experience in appreciation and expression; (3) art or music activities will help children in their development of positive attitudes towards school and reduce the rate of absence at school; (4) the involvement in art or music activities directly enhances the development of creativity; (5) a music or art education eases the social development, self adjustment, and intellectual development.

The results of the study show that art musicis crucial to be given to children mainly at the level of basic education. However, the phenomenon occuring in our country is thatart subject particularly music in elementary schools has not perfomed well yet, though the government has designed art and culture curriculum. Particularly in music, it can be seen from the low level of students' understanding about the basics of music theory, low competence of students in singing and playing music, and the teaching learning process that is less in accordance with the requirements of the standards of competence and basic competence (SK-KD). From several visits and mentoring by the researchers and PGSD Unesa team towardssome elementary school teachers in East Java (mentoring activities in schools), are always available to three problems of art education especially music as aforesaid. Even the reality in the field is also found: (1) teacher's lack of understanding about the basics of music theory, (2) teacher's lack of competence in performing the music teaching learning process, and (3) less support from the leader or the staff of educational department in improving the competence of music teachers, unlike the subjects of math, science, social science, civics, and Indonesian language. From the results of discussions with the teachers of elementary school, it is revealed that the main factor of the low quality of performing music teachingis mainly because teachers feel inadequate, not talented, and difficult in designing and performingthe music teaching learning material well.

These issues formed the basis of thought to develop a teaching kit that can assist teachers in carrying out the music learning in elementary schools. Furthermore the teaching kit is expected to lead to impact toward the increase of students' achievements inmusic learning in elementary schools. This research will be focused on the design of teachingkitwhich is appropriate to music learning in elementary schools, as well as how the level of conceptual, operational feasibility, and effectiveness.

The teaching kitproducedis all components that are used by teachers in their teaching learning process. The component in the study includes the learning scenarios in the syllabus, lesson plan $(R P P)$, teaching media, media usage instructions, students' worksheets $(L K S)$, and evaluation.

The teaching kit that will be developed is, among others: (1) instructional design of music material referred to PAKEM (active, effective, creative, and fun learning), which all are designed in the form of lesson plan and the teaching learning instruction; (2) the printed media which consist of a variety of music teaching learning media, student worksheet (LKS), reading materials of music; (3) non-printed media such as audio visual media in the form of an audio CD, VCD, and DVD. The selection and use of the audiovisual media have gone through consideration and are based on the reality on the ground, that generally in each elementary school has audio visual devices, such as DVD or VCD players, radio-tape, and television, even computers, so the use of audio visual media is relevant. The results are the music teaching learning kit, in addition to be used as music teaching learning materials for elementary school students, can also be used asa music learning instruction in some schools and various levels, even for a lecture in PGSD. This is because the subject matter is essentially reading the notation, the introduction of rhythm, melody and 
the basic of music theories in general, so that it can be applied to the level of elementaryschool to higher ones, of course with the adjustments to the lesson scenario.In particular, the use of the teaching kit of PAKEM in PGSD lecturesis expected to give inspiration to the prospective elementary school teachers, then to be used and developed as they become an elementary school practical teacher ora real teacher.

\section{METHOD}

This research uses the development model of Borg and Gall modified into 8 developmental steps, namely: (1) the study of the potential and problems; (2) the data collection; (3) the planning and development of products; (4) the product validation; (5) the product revision; (6) the field testing of products; (7) the product revision; and (8) the final product. The development model that is used in this research can be seen in Figure 1.

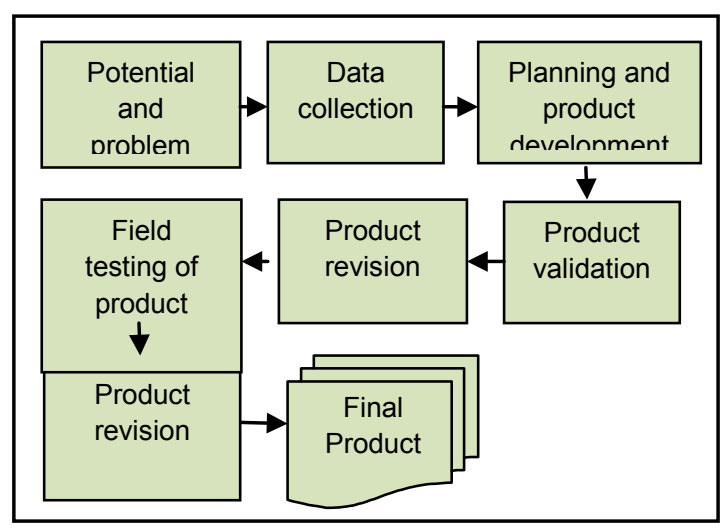

Figure 1. A Modified Borg and GallDevelopment Model

Despite having been through the process of modification, those eight steps still accomodate five essential points in a research development; they are 1) the study of the needs, problems, and potential available, 2) the procedure of developing product design, 3)the expert validation, 4) the field testing in product usage, and 5) the revision and final production. The procedure of conductin gthe development by researchers can be presented as Figure 2.

The teaching kith as been tested in the teaching learning process to get information on whether that development design is eligible or not, even if compared with the process before using the teaching kit. The field testing design uses the model of Randomized Posttest Only Control Group Design (Fraenkel, 2003, p. 273). The design uses two target groups of testing, namely the group of experiment (a treatment group) and the control group.

The collection of data in the research of development uses multiple data sources, including:

(1) Test method, to obtain data on the initial conditions of the experimental group and the control group, hereinafter called the pretest. This method is also implemented to measure the level of its homogeneity of samples. To measure the level of understanding and student learning outcomes after receiving treatment uses a test called a post-test.

(2) Documentation method, conducted to examine and obtain data about the curriculum of elementary schools, teaching materials, textbook, learning kit models, models of learning media, and scoring guideline. All information obtained will be used as the basic to construct the right product to be implemented in learning music in the third grade of elementary school.

(3) Observation method, performed to obtain qualitative data about the teacher activities in performing the music teaching process and the student activities in learning music.

(4) Survey method, which is carried out with two models namely open surveys and closed survey. An open survey is a model to obtain qualitative data in validation step, in order that data can be used as a reference in revising the developed product. A close survey is a model to obtain quantitative data about the product feasibility from the validator and to measure the product operational feasibility through the responses of teachers and students.

(5) Experimental method, performed to obtain quantitative data about the 


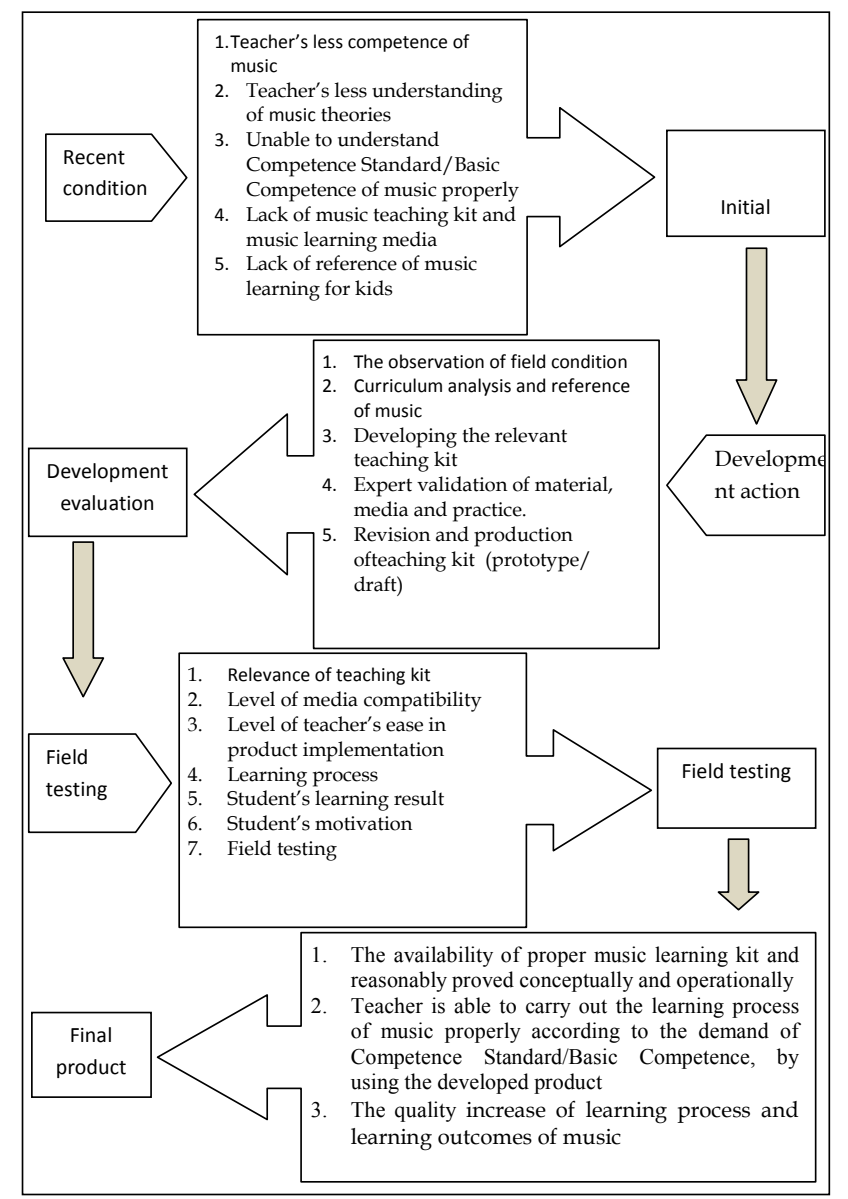

Figure 2. Flow of Music Teaching Learning Kit Development

product operational feasibility. The experiment done to measure whether the new learning kit is better than the old one.

\section{RESULTS AND DISCUSSION}

After observing the results of the previous study and the recent reference analysis about the music teaching learning, the researcher plans to develop products in order to improve the music teaching learning in elementary schools. The developed products in this study are a music teaching kit for the third grade of elementary schools, covering all the basic competence, namely: 1) Identifying various tone symbols of song, 2) Connecting the tone symbols with music elements, 3) Connecting the tone symbols with the tempo of the song, 4) Playing a simple rhythmic instrument,
5) Playing music in ensemble with simple rhythmic instruments, 6) Singing some traditional and kids' songs with simple accompaniment.

This teaching learning kit design is based on the analysis of the previous study and the recent references and the documents related to the innovative teaching kit. The developed kit in this study includes among others: 1) lesson plan with innovative music learning scenarios, 2) utilization instructions of the instrument, 3) non printed media involving video, animation, audio CDs,4) printed media, and (5) student worksheet (LKS). All kits are designed in a set for each basic competence. The formulation of product specifications is arranged through the steps performed as described below. 


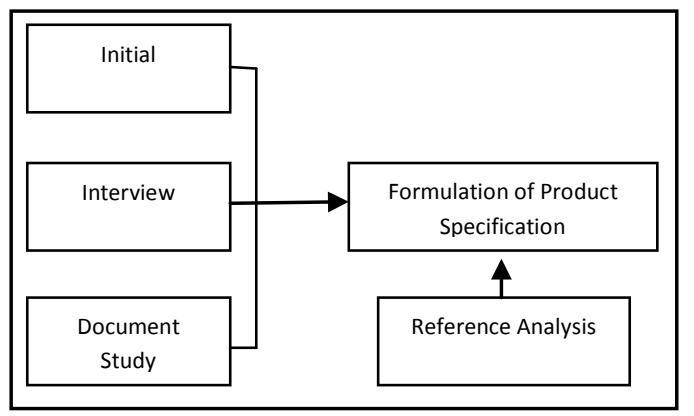

Figure 3. Flow of Plan of Product Design Steps

Then, the researcher arranges the music teaching learning kit for the third grade students of elementary schools by considering the conditions and intake from teachers about the problems of teaching learning process at school. The difficulties of a music teaching learning process in SD Lidah Kulon V are similar to those at most other schools; that is the teachers' less competence in understanding rhythm and melody, or in other words, teachers do not have good musical talent, as well as the limitations of teachers' knowledge about music theory. Based on such matters, the researcher wants to develop the music teaching kit which is good, innovative, and applicable. The word 'applicable' means the teacher is able to use the teaching kit easily and in a proper way. With a set design of music teaching kit based on the basic competence, hoping that the teachers will be easier in utilizing this teaching kit, since all the equipments are available for every meeting and specific learning objectives.

After going through the mapping of problems and current situation in the field, then carrying out the study of references, and considering the dialogue with practitioners in the field, the researcher makes the product design of multimedia teaching kit to improve music teaching learning in the third grade of elementary school. Due to the fact that teaching learning in elementary school has implemented models of active, creative, effective and fun learning approaches (PAKEM), the design of the planned products will refer to the design or scenario of PAKEM learning. This teaching kit product type is printed materi- als and non printed material, including lesson plan, student worksheet, evaluation, utilization instructions, video, animation, and learning audio.

Before the implementation of the trial, the researcher performs homogeneity test towards experimental group using Bartlett and ANOVA, and T test for testing between groups (value). Homogeneity test figures are 0.1177 for X2 count and 3.84 for X2table. It can be concluded that the two groups have no significant difference for the X2 count lower than the value X2 table.The result of the implementation of trial products will be analyzed as follows.

1. Teacher activity when performing the teaching process in experimental group and control group, show a pretty significant difference; that is the average score of control group is 2.25 while the experimental group is 3.56 out of a maximum score of 4 . In a percentage, the achievement level of teacher activity in the control group is $56.25 \%$, while the experimental group reaches $89.00 \%$. Therefore, it can be explained that the teacher activity in the process of teaching learning in the experimental group is better than that in the control group, with the difference figure up to $32.75 \%$.

2. Student activity in the control group and experimental groups shows significantly different scores. The average score of student activities in the control group is 2.40 , while in the experimental group 3.70 out of the maximum score 4 . In a percentage, the level of student activity in music learning in the control group is $60.00 \%$, and in the experimental group is $92.50 \%$. Thus, the different levels of student activity in the experimental group are higher than that in the control group, with the difference level up to $32.50 \%$.

3. Learning Outcomes of music in the two groups are compared and analyzed using T-Test. The data obtained in the music learning during the trial implementation can be seen in the following table. 
Table 1. Result of the T-Test

\begin{tabular}{ccc}
$\begin{array}{c}\text { Exp. } \\
\text { Group }\end{array}$ & $\begin{array}{c}\text { Aspects of the } \\
\text { Evaluation }\end{array}$ & $\begin{array}{c}\text { Control } \\
\text { Group }\end{array}$ \\
\hline 88.71 & $\begin{array}{c}\text { Test of art music } \\
\text { knowledge }\end{array}$ & 75 \\
89.29 & $\begin{array}{c}\text { Performance tests of } \\
\text { playing music }\end{array}$ & 62.39 \\
84.88 & Average & 68.70 \\
87.63 &
\end{tabular}

The calculation of T-Tests that the value of $t$ count $>$ the value of $t$ table, namely $9,212>1,670$. Thus, the values do not meet the criteria Ho: $\mathrm{u}_{1} \notin \mathrm{u}_{2}$ or it can be said Ho is declined.It means there is a positive difference in learning outcomes; that is the experimental group is better than the control group. Then the researcher measures the effectiveness of the development kit products towards learning outcomes of musical knowledge and ability to play music. The T-Test calculation of learning outcomes of musical knowledge measured by a written test shows the result as follows: $\mathrm{t}_{\text {count }}>\mathrm{t}_{\text {table }}\left(\mathrm{t}_{0,05} ; d f=66\right)$, with the score $6,284>1,670$. From the data it can be concluded that the experimental group gets a better achievement in musical knowledge than the control group. Then the test score of the ability to play music is $7,778>1,670$ or it can be said that $\mathrm{t}_{\text {count }}>\mathrm{t}_{\text {table }} \mathrm{t}_{0,05} ; d f=66$. Thus, the student's ability to play music in the experimental group is better than in the control group.

\section{CONCLUSION}

After performing a research involvingthe development process of teachingkit and the implementation of the field testing, it can be concluded that the limited capability of teachers in music teaching can be eliminated by the availability of good teaching kit. Through the utilization of the products of music teaching kit, teachers can perform the teaching learning of music well and meet the demands of the music curriculum. The music teaching learning is very specific since it demands a teacher's musical ability, which means a teacher has to master melodic and rhythmic skills. The weakness of teacher's musical ability is the cause of failure of a good process of music teaching learning. Audio and video media involving in this teaching kit are able to assist teachers in overcoming the obstacles in such musical capability limitations. Besides, the various design of teaching kit of $P A K E M$ and the utilization of interesting teaching media, significantly can increase the student interest to learn music, as well as raise their motivation to love and to learn music further. The more increasing the quality of music teaching process, the more significantly increasing the student learning outcomes, including musical knowledge and the ability to play music.

\section{REFERENCES}

Fraenkel, J.R. \& Wallen, N.E. (2003). How to Design and Evaluate Research in Education. Book 2. Boston: McGraw Hill.

Hartono. (2010). Pemanfaatan Media dalam Pembelajaran Tari di Taman Kanak-kanak. Harmonia: Journal of Arts Research and Education. 10 (1), 1-9.

Jazuli, M. (2008). Paradigma Kontekstual Pendidikan Seni. Surabaya: Unesa University Press.

Sugiono. (2011). Metode Penelitian Kuantitatif dan $R \mathcal{E} D$. Bandung: Alfabeta

Suherman, A. (2010). Model Pembelajaran Pakem dalam Pendidikan Jasmani di Sekolah Dasar. Jurnal Penelitian Pendidikan. 10 (1), 80-89. 